\title{
Proposed revised Bylaws and Articles of Incorporation
}

\section{www.mrs.org/elections}

In the April issue of MRS Bulletin,

Materials Research Society President Jim De Yoreo explained that the Board of Directors is proposing modifications to the legal documents that define how the Society is governed. He explained that "governance excellence" has been a high priority of the Board for the last few years, and one of the resulting activities was a thorough examination, in collaboration with legal advisors, of the

\section{MRS} MRS Constitution/Bylaws and the Articles of Incorporation. At the conclusion of this examination, proposed modifications were reviewed and approved by the Board and are now ready to be presented to the membership for ratification within the annual election ballot later this summer.

In the July issue, MRS Secretary Sean Hearne presented a comparison chart, illustrating the changes between the current documents and the proposed documents. Changes to the Articles of Incorporation are "housekeeping" and were suggested by legal counsel. Proposed changes to the current MRS Constitution/Bylaws, in essence, change the name of the Constitution portion to "Bylaws" and the information in the current Bylaws portion is to be transferred to the MRS Policy Manual.
There is no change to the privileges or rights of MRS members. What was always member-voted (current Constitution) will remain so for the new Bylaws; what was always Board-voted (current Bylaws) will remain so in the form of policies within the Policy Manual.

The final versions of the proposed Bylaws and Articles of Incorporation follow. They are also available on the MRS website at www.mrs.org/elections/ and will be accessible from the election ballot site during the election.

For more information or any questions, contact Sean Hearne, MRS secretary (secretary@mrs.org) or Kathy D’Biagio (dbiagio@mrs.org).

\section{Correction}

In the comparison chart to the Bylaws document printed in MRS Bulletin 36 (7) (2011) p. 547, Article IV, Section 2 should read: ". . . A two-thirds (2/3) vote of a minimum of $5 \%$ of all Members entitled to vote.

\section{Amended and Restated Articles of Incorporation of Materials Research Society}

\section{A Domestic Nonprofit Corporation}

1. The name of the Corporation is: Materials Research Society.

2. The address of the Corporation's registered office in this Commonwealth is:

506 Keystone Drive, Warrendale, Allegheny County, Pennsylvania 15086-7537.

3. The Corporation is organized exclusively for religious, charitable, scientific, literary, or educational purposes, including, for such purposes, the making of distributions to organizations that qualify as exempt organizations within the meaning of Section 501(c)(3) of the Internal Revenue Code of 1986, as amended (the "Code"), or the corresponding section of any subsequent Federal tax laws. The Corporation shall enjoy all of the purposes, powers and privileges conferred upon it by the Nonprofit Corporation Law of 1988,15 Pa.C.S.A. $\S \S 5101$ et seq.

4. The Corporation does not contemplate pecuniary gain or profit incidental or otherwise. The Corporation is organized on a non-stock basis.

5. The term for which the Corporation is to exist is perpetual. 